\title{
FIRE EVENTS AND VEGETATION DYNAMICS DURING THE LATE PLEISTOCENE-MEGHALAYAN INTERVAL IN THE SOUTHERNMOST BRAZILIAN COASTAL PLAIN
}

\author{
VERIDIANA RIBEIRO (D) \\ Programa de Pós-Graduação em Geografia, Centro Polar e Climático, Instituto de Geociências, Universidade Federal \\ do Rio Grande do Sul/UFRGS, Av. Bento Gonçalves, 9500, 91501-970, Porto Alegre, Rio Grande do Sul, Brazil. \\ very.ribeiro@yahoo.com.br
}

MARGOT GUERRA-SOMMER (D)

Programa de Pós-Graduação em Geociências, Instituto de Geociências, UFRGS, Av. Bento Gonçalves, 9500, 91501-970, Porto Alegre, RS, Brazil. margot.sommer@ufrgs.br

RUALDO MENEGAT

Departamento de Paleontologia e Estratigrafia, Instituto de Geociências, UFRGS, Av. Bento Gonçalves, 9500, 91501-970, Porto Alegre, RS, Brazil. rualdo.menegat@ufrgs.br

\section{LIDIA AUMOND KUHN (D)}

Programa de Pós-Graduação em Geociências, Instituto de Geociências, UFRGS, Av. Bento Gonçalves, 9500, 91501-970, Porto Alegre, RS, Brazil. lidiaak.lak@gmail.com

\section{JEFFERSON CARDIA SIMÕES (D)}

Programa de Pós-Graduação em Geografia, Centro Polar e Climático, Instituto de Geociências, UFRGS, Av. Bento Gonçalves, 9500, 91501-970, Porto Alegre, RS, Brazil. jefferson.simoes@ufrgs.br

\section{RICARDO BURGO BRAGA iD}

Laboratório de Gerenciamento Costeiro, Centro de Estudos de Geologia Costeira e Oceânica, Instituto de Geociências, UFRGS, Av. Bento Gonçalves, 9500, 91501-970, Porto Alegre, RS, Brazil. burgobraga@gmail.com

\section{SORAIA GIRARDI BAUERMANN ID}

Laboratório de Palinologia, Universidade Luterana do Brasil, Av. Farroupilha, 8001, 92425-900, Canoas, Rio Grande do Sul, Brasil. soraia.bauermann@ulbra.br

\section{WAGNER GUIMARÃES DA SILVA (D}

Instituto Federal de Educação, Ciência e Tecnologia do Rio Grande do Sul, Campus Restinga, Rua Alberto Hoffmann, 285, 91791-508, Porto Alegre, RS, Brasil. wagner.guimaraes.silva@gmail.com

\footnotetext{
ABSTRACT - The present study analyzes the correspondence between charcoal concentrations and changes in the palynological composition in a core from Águas Claras peatland (3006'24.39” S; 5049'04.90” W) in the coastal plain of southernmost Brazil (Rio Grande do Sul state) from approximately 38,900 yrs BP until 1,500 yrs BP. The dominance of grassland vegetation (mainly Poaceae) in Late Pleistocene sediments persisted into the Holocene during the development of a peatland. Analysis of fragment size distribution and concentration were useful to discriminate local fires from regional wildfires. Late Pleistocene regional fires registered in shallow pond deposits (older than 21,545 cal yrs BP) were distinguished from a local Holocene fire by the presence of higher proportions of small particles in charcoal assemblages. A charcoal peak related to a natural fire signal, composed by high concentration of charcoal with larger diameters, was identified at the topmost
} 
level of the peat facies $(1,590-1,515$ cal yrs BP). Correlated with palynological data, this charcoal peak originated by local fires indicates a change in vegetation during a dry climate interval that occurred around 1,500-1,600 yrs BP.

Keywords: charcoal peak, palynology, climate, Holocene.

\begin{abstract}
RESUMO - O presente estudo analisa a correspondência entre as concentrações de carvão vegetal e as alterações na composição palinológica em um testemunho sedimentar da turfeira de Águas Claras (3006’24.39” S; 5049'04.90”W) na planície costeira do extremo sul do Brasil (Rio Grande do Sul) em um intervalo de cerca de 38.900 anos AP a 1.500 anos AP. A dominância de vegetação herbácea (principalmente Poaceae) no intervalo glacial tardio do Neopleistoceno persistiu até o Holoceno, durante o desenvolvimento de uma turfeira. A análise da distribuição e concentração de tamanho dos fragmentos de charcoal foi utilizada para distinguir incêndios florestais locais de incêndios regionais. Incêndios regionais no Neopleistoceno (mais antigos do que 21.545 anos cal AP) foram diferenciados de um incêndio local do Holoceno, dadas as grandes quantidades de pequenos fragmentos de charcoal com diâmetros semelhantes. Um pico de charcoal que corresponde a um sinal incêndio natural, composto por alta concentração de fragmentos com grandes diâmetros indicando incêndio local, foi identificado no nível de topo de fácies originadas em turfeira (1.590-1.515 anos cal AP). Esse pico de charcoal, correlacionado aos dados palinológicos, indicou uma mudança na vegetação relacionada a um intervalo climático de seca que ocorreu por volta de 1.500-1.600 anos AP.
\end{abstract}

Palavras-chave: pico de carvão vegetal, palinologia, clima, Holoceno.

\section{INTRODUCTION}

Fire is the dominant disturbance agent in most terrestrial ecosystems (Bowman et al., 2009), and is a key ecological process affecting vegetation dynamics and land cover (Iglesias et al., 2015). The fire regime results from complex interactions between long-term trends in climate, local fuel availability, and the probability of ignition (Heyerdahl et al., 2008).

Charcoal, which is formed from the incomplete combustion of fuel under reducing conditions, has been used in combination with other paleo-environmental proxies to analyze climate-fire-vegetation linkages (Clark \& Royall, 1995; Gavin et al., 2006).

Syntheses of charcoal records on the Holocene, which started about 11,650 cal yrs BP (Masson-Delmotte et al., 2013), led to the Global Charcoal Database (Power et al., 2008; Marlon et al., 2009; Daniau et al., 2012; Marlon et al., 2013). The database includes a large number of metadata records from both macroscopic and microscopic charcoal, from different sites (lake, lagoon, mire, and alluvial-fan sediment), with varying temporal resolution and dating control. Nevertheless, these data have marked spatial heterogeneity in the sample-site distribution, and some regions, such as southern South America, are generally poorly represented.

Charcoal records from South America suggest that fire is a natural component of arid (Paduano et al., 2003), temperate and cool-temperate (Huber et al., 2004; Whitlock et al., 2007; Markgraf et al., 2013), and tropical wet (Cordeiro et $a l ., 2008)$ biomes. The occurrence of fires during the Late Pleistocene-Meghalayan in the highland grasslands (Campos) ecosystem in southernmost Brazil was inferred by putative burned fragments observed in palynological slides (Behling, 1995; Behling et al., 2004).

The present study was based on the correlation between charcoal variability and changes in the key pollen taxa in different paleoenvironments detected in a single profile, which helped identifying vegetation responses to past fire events (Green, 1981; Patterson \& Backman, 1988; Rhodes \& Davis, 1995; Larsen \& MacDonald, 1998; Whitlock \& Bartlein, 2003; Whitlock et al., 2007; Boyle et al., 2011). The goal was to test whether fire-vegetation linkages could be identified through the cross-correlation between charcoal assemblages and palynological composition along a profile obtained in the Águas Claras peatland in the coastal plain of Rio Grande do Sul, the southernmost Brazilian state. The profile represents deposition in a freshwater environment during the Late Pleistocene, which has evolved to a peatland in the Late Holocene. In order to assess connections between fire events and climatic fluctuations, palynological and charcoal analyses are supported by a detailed faciological description and paleoenvironmental interpretation.

The studied area is included in the "Campos del Norte Region” as defined by León (1991) for the Río de la Plata grasslands, which extends from Uruguay across southern Rio Grande do Sul and into the boundary between the "Campos Arbustivos" and "Campos do Centro do Estado", as defined by Boldrini et al. (2010), Hasenack et al. (2010) and Mourelle et al. (2018).

\section{GEOLOGICAL SETTING}

The low-relief coastal plain of Rio Grande do Sul is the onshore portion of the Pelotas Basin, which was installed in Early Cretaceous during the opening of the South Atlantic Ocean (Villwock \& Tomazelli, 1995). This basin lies on Precambrian rocks of the Sul-Rio-Grandense Shield and Paleozoic and Mesozoic volcanic-sedimentary sequences of the Paraná Basin (Villwock \& Tomazelli, 1995).

The sedimentary record of the 20 to $80 \mathrm{~km}$ wide coastal plain of Rio Grande do Sul is constituted by the succession of four barrier-lagoon systems built during the Middle Pleistocene and Holocene. The barrier successions were driven by four events of rising sea levels in the last $400 \mathrm{kyrs}$ 
BP. The three older barrier systems, known as Systems I, II, and III, were formed during the Pleistocene, and the youngest (System IV) during the Holocene. The modern configuration of the still-active System IV dates back to the final stages of the Post Glacial Marine Transgression at about 7 kyrs BP (Villwock et al., 1986; Dillenburg et al., 2009).

The morphological elements of the barrier-lagoon systems represent ancient coastal depositional environments corresponding to ancient lagoons, lakes, relict and active transgressive dune fields, fore dune ridges, and other architectural elements that compose each system (Barboza et al., 2005; Dillenburg et al., 2009).

The Águas Claras peatland is located on the inner landward portion of the coastal plain and was formed during the deposition of the Lagoon-Barrier System IV according the criteria of Villwock et al. (1986) and Dillenburg et al. (2009).

This $32.1 \mathrm{~km}^{2}$ area is positioned at altitudes between 10 and $15 \mathrm{~m}$ pertains to the southern edge of the Gravataí River floodplain. The elongated axis of the peatland follows the NE-SW-oriented sand ridge called Coxilha das Lombas (146 m high), which corresponds to the relictual barrier of the Lagoon-Barrier System I (Figure 1).

\section{METHODOLOGY}

\section{Drilling technique}

Samples for various analyses were recovered from a 2.3-meter-long and $75 \mathrm{~mm}$ in diameter sediment core obtained by percussion drilling technique using a polyvinyl chloride tube (PVC).

\section{Sedimentological profile}

The facies description and analysis were based on Walker $(1992,2006)$ and Miall (1992) concepts and techniques. The facies were identified according to sediment color and texture, sedimentary structures and grouped in facies associations. The chronostratigraphic framework was established from radiocarbon dating (calibration curve) obtained by Beta Analytic Inc., Florida (USA), from samples collected in different sedimentary textures of the profile. An additional radiometric dating was obtained at a depth of $17 \mathrm{~cm}$. Grain size was measured with a laser Horiba particle analyzer system (model LA-950V2).

Detailed facies analysis was performed for paleoenvironment interpretation and the description of the stratigraphic framework. The total organic matter content was determined by burning $3 \mathrm{~g}$ of sediment for $24 \mathrm{~h}$ and then heating in a muffle at $550^{\circ} \mathrm{C}$ for $4.5 \mathrm{~h}$. The relationship between the initial and final weight was obtained according to the criteria of Wetzel (1975).

\section{Charcoal}

For the charcoal analysis, a volume of $4 \mathrm{~cm}^{3}$ was collected at $10 \mathrm{~cm}$ intervals along the $2.30 \mathrm{~m}$ drill core. Samples were placed in an oven at room temperature $\left(20^{\circ} \mathrm{C}\right)$ for $48 \mathrm{~h}$. The unconsolidated sediment was then manually disaggregated, and the potential macroscopic charcoal fragments were examined under a 20x stereomicroscope (Leica S8APO) coupled with a digital camera in a Petri dish with the aid of a fine brush.

Potential macroscopic charcoal fragments were identified by physical proprieties, such as black color, silky luster, brittleness, and good anatomical preservation (Scott, 2000, 2010). These particles were also counted and measured under the stereomicroscope.

The particles considered as possible charcoals were analyzed with scanning electron microscopy (SEM) analysis to identify the homogenization of cell walls and anatomical peculiarities according to the criteria of Scott $(2000,2010)$, which considers fragments $<180 \mu \mathrm{m}$ as micro-charcoal, fragments from $180 \mu \mathrm{m}$ to $1 \mathrm{~mm}$ as meso-charcoal, and fragments $>1 \mathrm{~mm}$ as macroscopic charcoal. The inference of intensities and duration of fire events were based on total homogenization or partial homogenization of the cell wall (Scott, 2000). The results are presented graphically showing concentration and size of the particles (Figure 2, right column). The charcoal chronology was constructed based on the linear succession of calibrated ages.

\section{Palynology}

To identify the paleovegetation and the changes in its composition resulting from fire peaks, six samples of $1 \mathrm{~cm}^{3}$ along the core drill were collected for palynological analysis at different depths representing pre-fire, fire, and post-fire intervals (at depths of 117, 67, 22, 18, 17 and $14 \mathrm{~cm}$ ). All processing techniques for palynological analysis were performed in the Laboratório de Palinologia Marleni Marques Toigo, Instituto de Geociências, Universidade Federal do Rio Grande do Sul (LPMMT/IG/UFRGS).

The samples were prepared according to the standard techniques for pollen analyses of Quaternary sediments (Ybert et al., 1992), modified by $\mathrm{HF}, \mathrm{HCl}, \mathrm{KOH}$, and acetolysis, sequentially, and then filtered through a $250 \mu \mathrm{m}$ mesh sieve. Four permanent slides of each sample were prepared using Entellan. A minimum of 300 pollen grains was counted for each subsample (Mosimann, 1965).

The counts were carried out under 400x magnification, and the systematic determination was made on the basis of morphological and morphometric characteristics of sporomorphs with $1000 \mathrm{x}$ magnification. Pollen identification was based on catalogs of published palynomorphs as well by comparison with modern equivalents in pollen reference collections ("MP-Pr" slides of LPMMT/IG/UFRGS).

The pollen sum included trees, shrubs, and herbs. Pteridophytes, moss spores, and algae were also counted, constituting a separated list expressed as the percentage of the total pollen sum. The relative value of each palynomorph was calculated as a percentage of the total pollen sum (total pollen grains) (Faegri \& Iversen, 1989). 

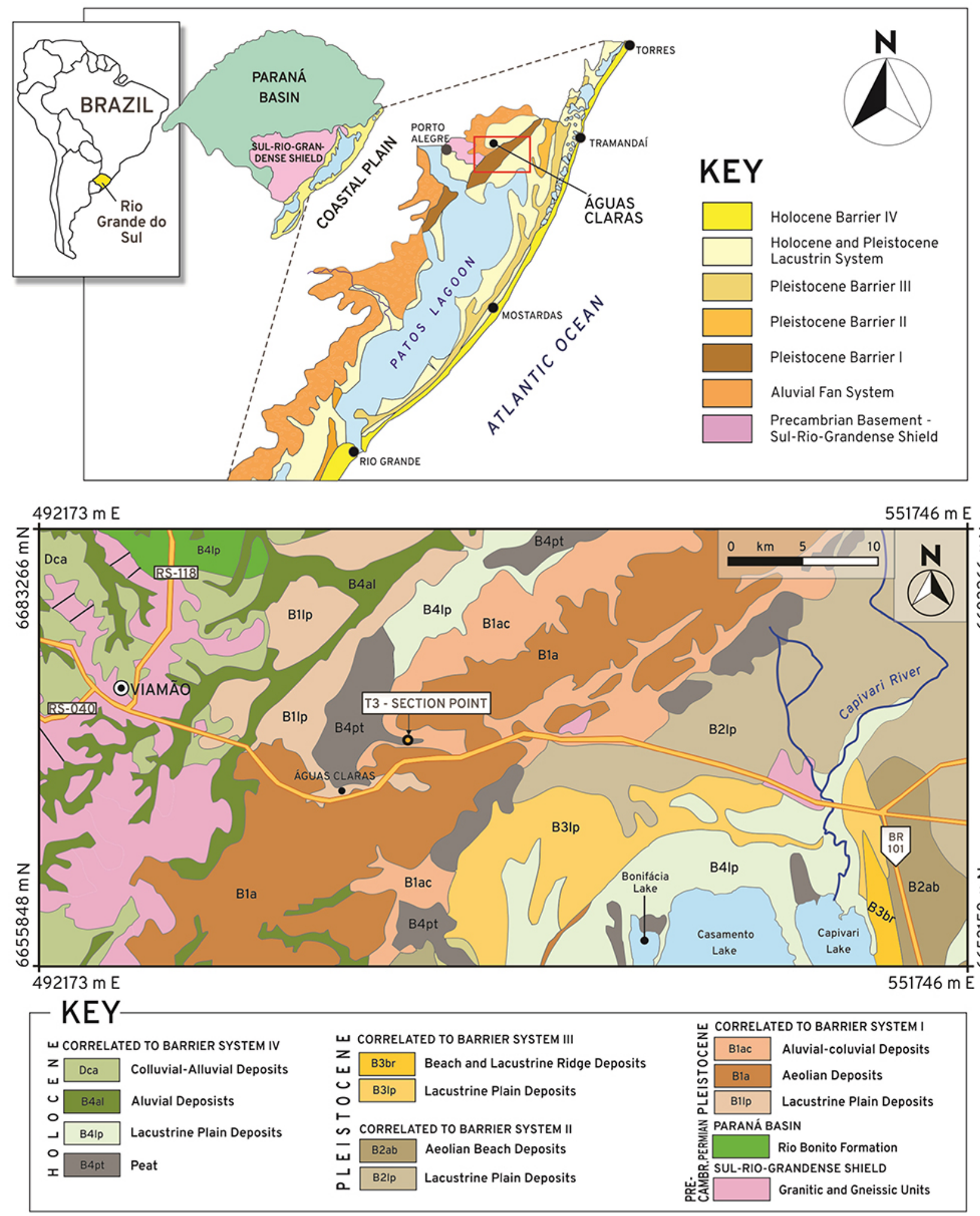

Figure 1. Location map of Coastal Plain of Rio Grande do Sul (Tomazelli \& Villwock, 1996 and Stevaux \& Dillenburg, 2011) and geological map and location of T3 section point (adapted from CPRM, 2006). 


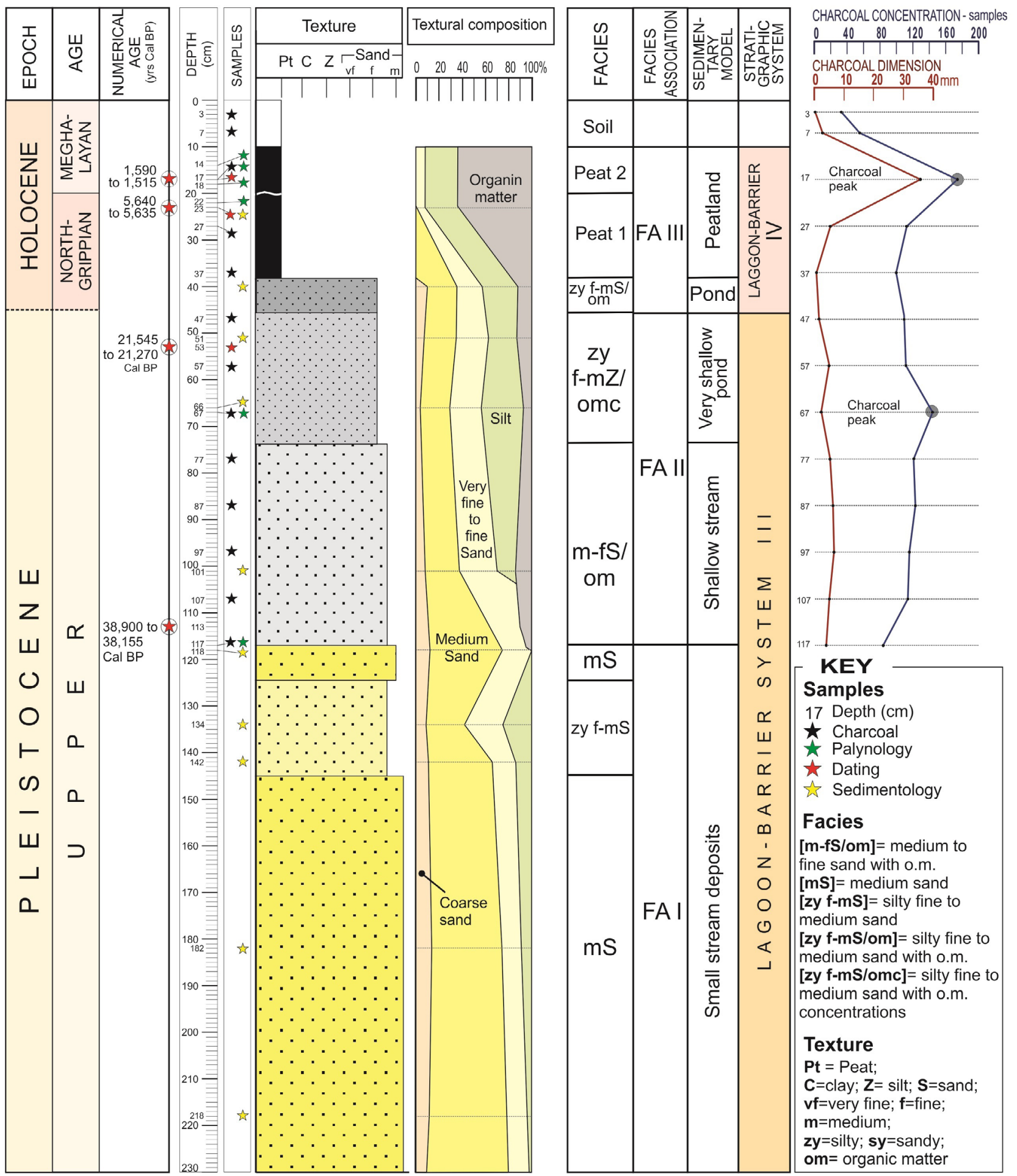

Figure 2. Columnar profile of Águas Claras peatland showing facies succession, geochronology and geochronological units, charcoal concentration, and charcoal dimension. 


\section{RESULTS}

\section{Stratigraphic profile}

The stratigraphic profile (Figure 2) comprises three facies associations, called, from base to top. Facies Associations (FAs) I, II, and III, which include a total of eight facies characterized by textural variation, organic matter content, and color. Codes, description, and interpretation of different facies are described in Table 1.

The 1.12-m thick basal FA I, at a depth of 1.18 to $2.30 \mathrm{~m}$ includes three facies. At the base, the medium sand facies [mS] without apparent structures, is overlain by silty medium to fine sand [zy-f-mS], followed by a centimetric layer of medium sand $[\mathrm{mS}]$ all without organic matter. These facies of medium sand also contain the highest proportions of coarse sand that represent a small stream deposit. In addition, the absence of clay along the FA I suggests that stagnant water bodies were not formed in this area.

The intermediate 73-cm-thick FA II occurs at a depth between 0.45 and $1.18 \mathrm{~m}$, and includes a medium to finesand facies [m-fS/om] with $4.87 \%$ to $13.51 \%$ organic matter and about $9 \%$ of coarse sand and $19 \%$ of silt, interpreted as a shallow stream deposits. This basal facies is overlain by a 30 -cm-thick silty very-fine to medium-sand with organic matter concentration facies [zy-f-mS/omc] with $6.98 \%$ to $11.74 \%$ organic matter inferred as a very shallow pond. Both FA I and FA II are correlated with the Lagoon Barrier System III of Villwock et al. (1986) and Dillenburg et al. (2009). The uppermost 45-cm-thick FA III correlated with the Lagoon-Barrier System IV encompasses a 7-cm-thick silty very-fine to medium-sand facies [zy-f-mS/om] with $11.56 \%$ organic matter interpreted as pond deposits. This basal facies is overlain by an 18 -cm-thick Peat 1 facies with $30.00 \%$ of organic matter. In turn, the uppermost facies of the FA III is the 10 -cm-thick Peat 2 facies with $65.53 \%$ organic matter. These last two facies represent a peatland environment.

\section{Dating}

Calibrated radiocarbon datings indicate that the studied interval of the core spans the last 38,900-38,155 cal yrs BP, comprising a time interval from the Late Pleistocene to the Late Holocene (1,590-1,515 cal yrs BP). Charcoal chronology was constructed based on the linear succession of calibrated ages (Table 2).

\section{Charcoal}

Charcoalized fragments ranging from $1.35 \mathrm{~mm}$ to $34 \mathrm{~mm}$ in length, characterized as macrocharcoal, were recovered from each of the 12 sampling levels at the studied core (Figure 2). The fragments showed generally well-preserved anatomical details and homogenized cell walls (Figure 3), which are typical characteristics of charcoals under SEM (Scott, 2010).

The anatomical details linked almost charcoal with the xylem of angiosperms, and the common presence of parenchyma tissues (Figure 3E) seems to indicate monocot affinities, but the absence of a more detailed systematic approach limits any taxonomic conclusion.

The association between concentration and size of charcoals from $117 \mathrm{~cm}$ to $7 \mathrm{~cm}$ depth of the studied core led to the construction of a curve represented in the Figure 2 (right). Some characteristics of the charcoals that could give information about fire events, i.e. total homogenization of cell walls, which indicates intense and/or long duration fires, and partial homogenization of the cell wall linked to low intensity and/or short duration fires (Scott, 2010), were identified during the description of charcoal assemblages.

Table 1. Codes, description, and interpretation of facies.

\begin{tabular}{|c|c|c|c|}
\hline Facies Code & Description & Interpretation & Facies Association \\
\hline [Peat 2] & $\begin{array}{l}\text { Dark gray peat with } 65.53 \% \text { organic matter, } 26.23 \% \text { silt and } \\
8.24 \% \text { of quartzose very fine sand. }\end{array}$ & Peatland accumulation & FA III \\
\hline [Peat 1] & $\begin{array}{l}\text { Dark gray peat, with } 54.45 \% \text { of organic matter, } 27.52 \% \text { silt, } \\
8.12 \% \text { of very fine sand, and } 9.91 \% \text { quartzose medium sand. }\end{array}$ & Peatland accumulation & FA III \\
\hline [zy-f-mS/om] & $\begin{array}{l}\text { Silty very fine to medium sand } \\
\text { with } 12.72 \% \text { organic matter, } 35.65 \% \text { silt, } 26.56 \% \text { very fine to } \\
\text { fine sand, } 22.27 \% \text { medium sand, and } 2.8 \% \text { coarse sand, without } \\
\text { apparent structure. }\end{array}$ & $\begin{array}{l}\text { Deposition in low energy environment } \\
\text { with accumulation of organic matter; some } \\
\text { traction in lower flow regime; flat bed form }\end{array}$ & FA III \\
\hline [zy-f-mS/omc] & $\begin{array}{l}\text { Silty very fine to medium sand with organic matter } \\
\text { concentration } \\
\text { with } 9.8 \% \text { of organic matter, } 35.43 \% \text { silt, } 26.01 \% \text { very fine to } \\
\text { fine sand, } 25.67 \% \text { medium sand and } 3.09 \% \text { coarse sand, scarcely } \\
\text { little thin lens of organic matter concentration. }\end{array}$ & $\begin{array}{l}\text { Deposition in low energy environment and } \\
\text { accumulation of organic matter }\end{array}$ & FA II \\
\hline [m-fS/om] & $\begin{array}{l}\text { Medium to fine sand with } 8.25 \% \text { of organic matter, } 19.12 \% \\
\text { silt, } 40.27 \% \text { medium sand, } 28.56 \% \text { very fine to fine sand, and } \\
3.8 \% \text { coarse sand, without apparent structure. }\end{array}$ & $\begin{array}{l}\text { Shallow/intermittent water body with } \\
\text { accumulation of organic matter }\end{array}$ & FA II \\
\hline [zy-f-mS] & $\begin{array}{l}\text { Silty fine to medium sand, with } 24.62 \% \text { silt, } 41.32 \% \text { medium } \\
\text { sand, } 24.76 \% \text { very fine to fine sand, and } 9.30 \% \text { coarse sand, } \\
\text { without apparent structure. }\end{array}$ & $\begin{array}{l}\text { Subaqueous traction in lower flow regime } \\
\text { and flat deposits of small stream. }\end{array}$ & FAI \\
\hline$[\mathrm{mS}]$ & $\begin{array}{l}\text { Medium sand, with } 8.46 \% \text { silt, } 65.22 \% \text { medium sand, } 15.04 \% \\
\text { very fine to fine sand, and } 11.28 \% \text { coarse sand, without apparent } \\
\text { structure, some levels with oxidation. }\end{array}$ & $\begin{array}{l}\text { Predominance of subaqueous traction in } \\
\text { lower flow regime of small stream }\end{array}$ & FAI \\
\hline
\end{tabular}


Table 2. AMS radiocarbon ages used to build the age-depth model of the core $\mathrm{T} 3$.

\begin{tabular}{lccc}
\hline Depth $(\mathrm{cm})$ & ${ }^{13} \mathrm{C}$ yr BP & $\begin{array}{c}\text { Laboratory } \\
\text { number }^{\mathrm{a}}\end{array}$ & $\begin{array}{c}\text { Calibrated ages } \\
(\text { cal yrs BP })\end{array}$ \\
\hline 17 & $1,690 \pm 30$ & $\mathrm{~b} 439990$ & $1,590 \geq 1,515$ \\
23 & $4,890 \pm 30$ & $\mathrm{~b} 395575$ & $5,640 \geq 5,635$ \\
53 & $17,730 \pm 50$ & $\mathrm{~b} 395575$ & $21,545 \geq 21,270$ \\
113 & $34,060 \pm 230$ & $\mathrm{~b} 396001$ & $38,900 \geq 38,155$ \\
\hline
\end{tabular}

${ }^{\text {a }}$ Samples were processed by Beta Analytic.
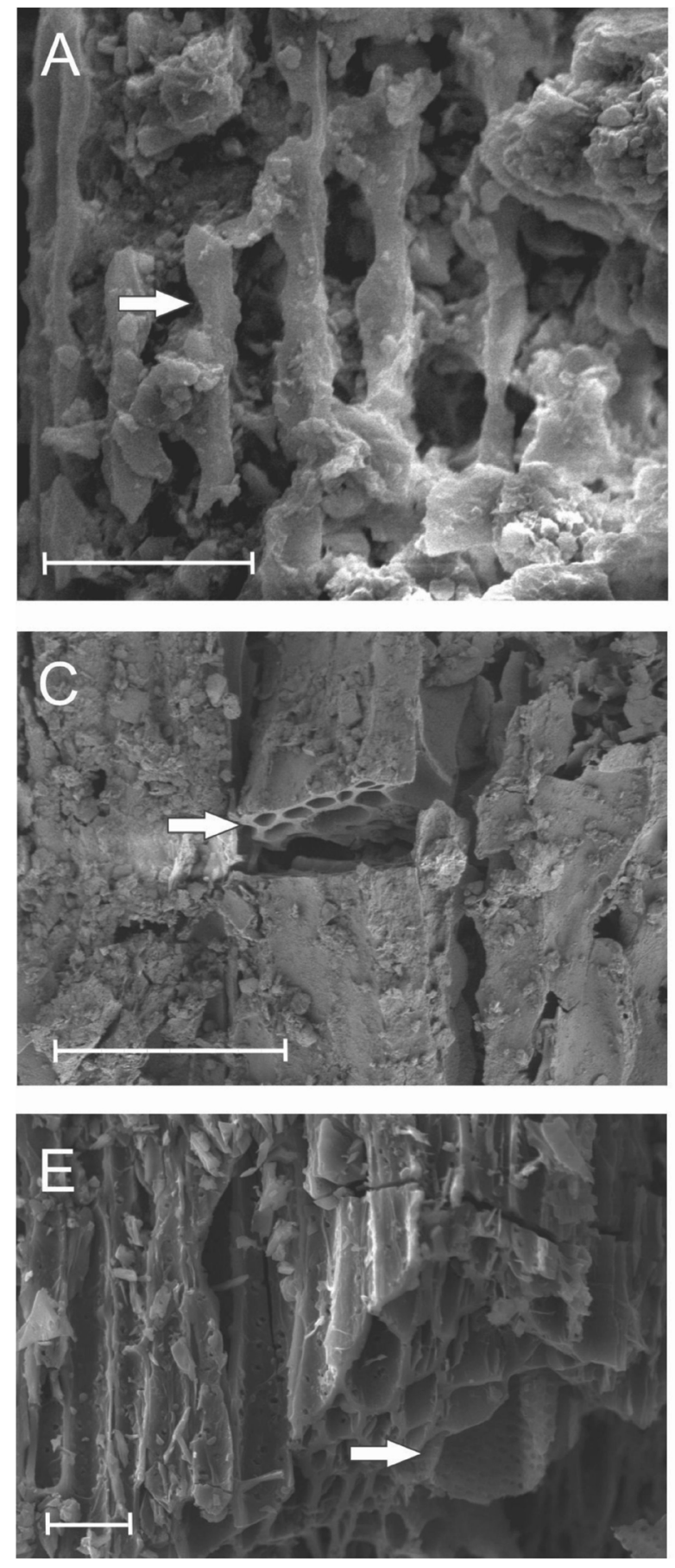

Figure 3. Photomicrographs of macrocharcoals retrieved from the Águas Claras core. A-B, mineralized charcoals from the base of the lacustrine environment. $\mathbf{C}-\mathbf{D}$, fragments from the charcoal peak in shallow pond environment. E-F, fragments from the charcoal peak in the peatland environment. Arrows point to homogenized cell walls. Scale bars $=20 \mu \mathrm{m}$.

Charcoal analyses from the basal FA I, that correspond to small stream deposits (older than 38,900 yrs BP), revealed that the medium-to-fine sands were sterile, without organic matter accumulation. At base of the FA II (Figure 2), at the depth of $117 \mathrm{~cm}$, the macrocharcoal found in $\mathrm{m}-\mathrm{fS} / \mathrm{om}$ facies, that represent shallow stream deposits, are small to medium size (from 3.86 to $5.34 \mathrm{~mm}$ ). The charcoalized fragments showed intense surface mineralization, and in spite of been anatomically poorly preserved, presented complete homogenization of cell walls (Figures 3A and B). At the depth
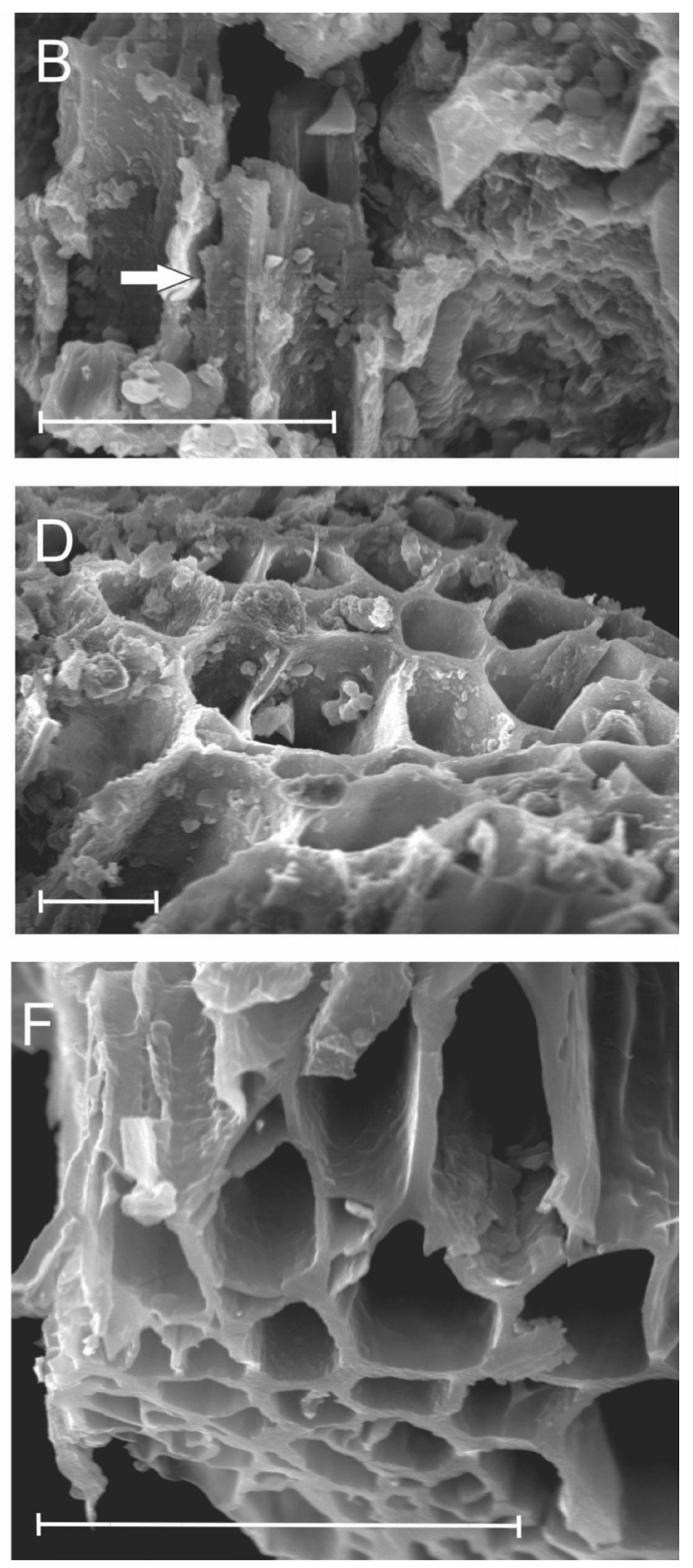
of $107 \mathrm{~cm}$, the composition of the burned fragments found in [m-fS/om] facies changed significantly and becomes largely dominated by non-mineralized charcoals; however, scarce fragments $(5 \%)$ of mineralized charcoals are still present. Charcoal fragments showing partially homogenized cell walls occur mixed with fragments showing total homogenization of the cell wall. From the topmost portion of the [m-fS/om] facies interpreted as shallow stream deposits (depth of $77 \mathrm{~cm}$ ) until the depth of $67 \mathrm{~cm}$ ([zy-f-mS/omc] facies) considered as very shallow pond, the concentration of charcoal increased gradually whereas their small size remained unchanged. Mineralized fragments are totally absent, and the charcoal assemblage is characterized by the highest concentration of small, almost similar size charcoal fragments (average $4 \mathrm{~mm}$ ) (Figure 2 right, Figures $3 \mathrm{C}$ and D).

At the depth of $67 \mathrm{~cm}$ the charcoal concentration decreased gradually, but the fragments size characteristics remained unchanged until the depth of $57 \mathrm{~cm}$ (older than 21,545-21,270 cal yrs BP) featuring a smooth positive curve (Figure 2 right). The general anatomic characteristics, besides size and concentration of the charcoal assemblage remained unchanged until the topmost FA II ([zy-f-mS/omc] facies) and also during the deposition of basal [zy-f-mS/om] facies (depths of 46 to $38 \mathrm{~cm}$ ) of the FA III related to pond deposits. Nevertheless, at the transition from the [zy-f-mS/om] facies (depth of 37 $\mathrm{cm}$ ) to the Peat facies 1, it was observed a gradual increase of both parameters, respectively dimension and concentration of charcoals, which became very expressive at the depth of $27 \mathrm{~cm}$ (older than 5,640-5,635 cal yrs BP), culminating in a peak in the depth of $17 \mathrm{~cm}(1,590-1,515 \mathrm{cal}$ yrs BP) at the beginning of the deposition of the Peat facies 2. At this level, macrocharcoal reached maximum concentration and diameter $(34 \mathrm{~mm})$ of the profile and cell walls are totally homogeneized in almost non-abraded fragments (Figure 2 right). From the peak towards the top of the Peat facies 2 (depth of $7 \mathrm{~cm}$ ), the concentration and the dimensions of the charcoal fragments decreased abruptly and persisted at low levels in the soil.

\section{Palynology}

Palynological analysis from the base of the FA II ([m$\mathrm{fS} / \mathrm{om}$ ] facies) at the depth of $117 \mathrm{~cm}$ (Figure 5) indicated that the most representative palynomorphs are herbal pollen grains $(87.7 \%)$, mainly of Poaceae (41.2\%), Asteraceae subf. Asteroideae (27.4\%) and Apiaceae (15.4\%). The trees reached $12.3 \%$, especially Myrtaceae (8.6\%), Mimosoideae $(1.2 \%)$ and Ilex (1\%). The bryophyte spores are absent and pteridophytes are poorly represented (3.1\%) with Blechnum and Polypodiaceae. Fresh water taxa are very rare and represented by algal mats of Botryococcus $(2.9 \%)$ and spores of Spirogyra (1.3\%).

The most representative palynomorphs from the charcoal peak at the depth of $67 \mathrm{~cm}$ (FA II [zy-f-mS/omc] facies) are herbal pollen grains $(94.6 \%)$ of Poaceae $(42.4 \%)$, Asteraceae subf. Asteroideae (37\%) and Apiaceae (7.9\%). The trees reached 5.4\%, with emphasis on Mimosoideae (2.7\%), Celtis (1.4\%) and Myrtaceae (1.1\%). Pteridophytes increased to $14.7 \%$, with Blechnum (14.6\%) and Polypodiaceae $(0.1 \%)$. The bryophyte spores are $1.1 \%$ with Sphagnum and Phaeoceros. At this level, aquatic taxa are very rare, but it was observed an increase in spores of Spirogyra (3.6\%), a decrease in Botryococcus blooms $(0.3 \%)$ and the very rare presence of Zygnema (0.3\%) (Figure 4).

Palynological analyses from the peat sample collected at the depth of $22 \mathrm{~cm}$ (FA II [Peat 1] facies) indicated that the most representative palynomorphs are herb pollen grains $(90.8 \%)$, mainly Poaceae (54.6\%), Asteraceae subf. Asteroideae (32.1\%) and Apiaceae (3.5\%). The trees reached $9.2 \%$, especially Celtis (2\%), Ericaceae (2\%), Myrtaceae (1.4\%) and Sebastiania (1.2\%). Trema, Alchornea and Sapium genera appear for the first time in the core. The spores of bryophytes increased to $11.1 \%$ with Sphagnum and Phaeoceros, and pteridophytes decreased to $10.5 \%$ with Blechnum (9.2\%), Isoetes (0.9\%) and Polypodiaceae ( $0.4 \%)$. Aquatic taxa are found only in trace amounts represented by algae spores of the genus Pseudoschizaea (0.9\%) (Figure 4).

At the depth of $18 \mathrm{~cm}$ (FA III, [Peat 2] facies), just before the charcoal peak, the dominant palynomorphs are herbal pollen grains $(87.5 \%)$, with taxa of Poaceae $(53 \%)$, Asteraceae subf. Asteroideae (30.6\%) and Apiaceae (2.6\%). The trees reached $12.5 \%$, especially Ericaceae (7.9\%), Alchornea, Myrtaceae and Sapium (1.3\%). The spores of bryophytes reached the maximum in the samples (20\%) with Sphagnum and Phaeoceros, as well as pteridophytes (40.3\%) with Blechnum (37.1\%), Marattia (1.8\%), Anogramma (0.9\%) and Polypodiaceae (0.5\%). Pseudoschizaea remained as the single aquatic taxon recorded at this level $(0.8 \%)$.

The dominant palynomorphs from the charcoal peak at depth of $17 \mathrm{~cm}$ are herbal pollen grains $(92.7 \%)$, with taxa of Poaceae (60.5\%), Asteraceae subf. Asteroideae (24.9\%) and Apiaceae (4.7\%). The trees reached $7.3 \%$, especially Myrtaceae (5.3\%), Celtis (1.3\%), Ericaceae $(0.3 \%)$ and Arecaceae $(0.3 \%)$. The spores of bryophytes decreased to $11.4 \%$, with Sphagnum and Phaeoceros, as well as pteridophytes (18.4\%) with Blechnum (14.4\%), Anogramma (2.8\%), Polypodiaceae $(0.7 \%)$ and Marattia $(0.5 \%)$. Aquatic taxa were absent in this charcoal peak.

The most representative palynomorphs at the depth of 14 $\mathrm{cm}$, after the charcoal peak are herbal pollen grains (95.3\%), with taxa of Poaceae (48.6\%), Asteraceae subf. Asteroideae (42\%) and Apiaceae (4.7\%). The trees decreased to $4.7 \%$, being represented only by Myrtaceae (3.8\%), Celtis (0.3\%), Allophylus $(0.3 \%)$ and Arecaceae $(0.3 \%)$. The spores of bryophytes stayed at a percentage of $11.5 \%$ with Sphagnum and Phaeoceros, and pteridophytes at $15.9 \%$ with Blechnum $(14.9 \%)$, Marattia $(0.5 \%)$ and Polypodiaceae $(0.5 \%)$. The green alga Pseudoschizaea is the single taxon of aquatic forms $(0.5 \%)$ (Figures 4 and 5$)$. 

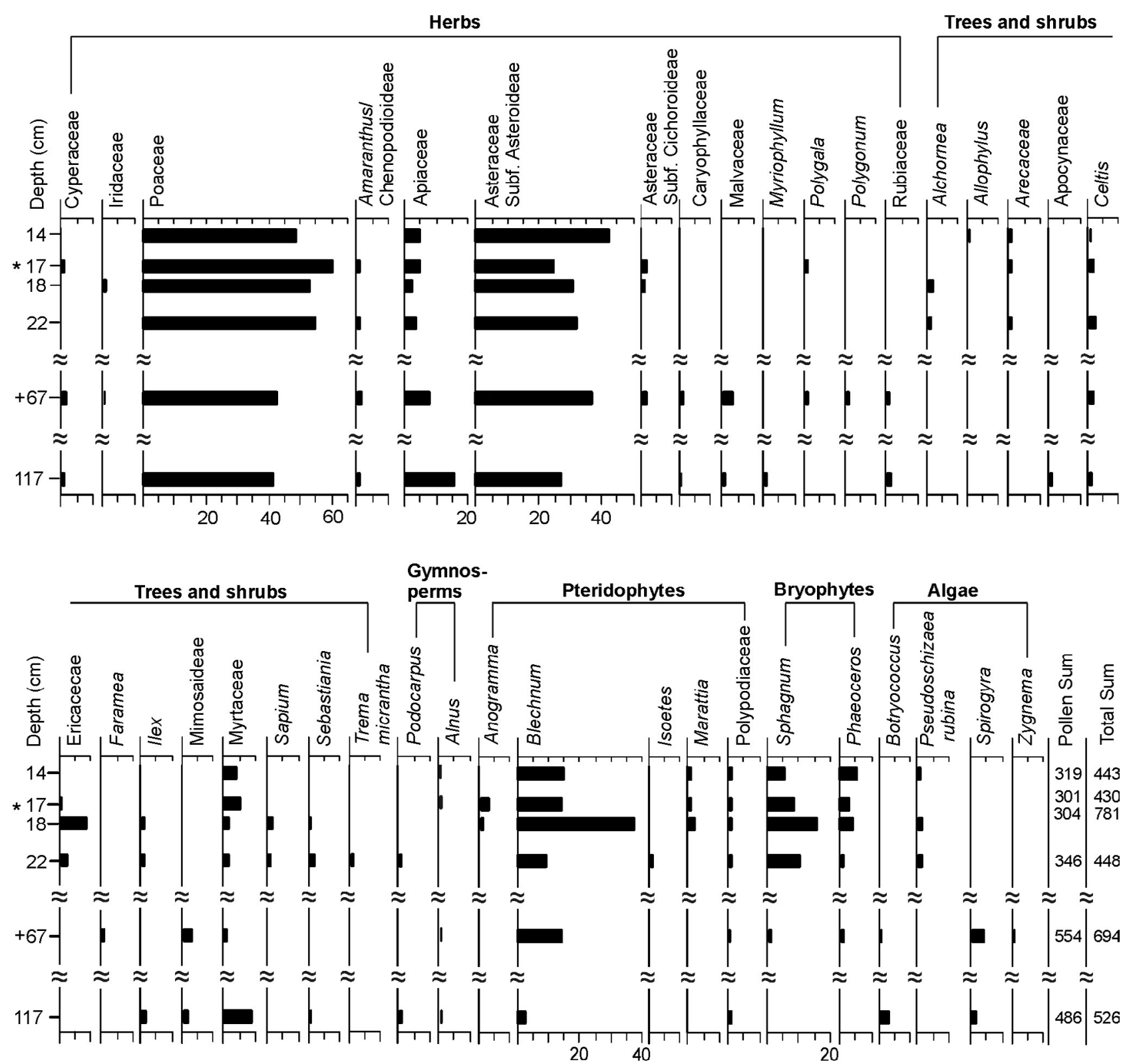

Figure 4. Percentage diagram of the palynomorphs showing the frequency of pollen grains, spores and algae taxa from the core grouped into herbs, trees, and shrubs, pteridophytes, gymnosperms, ferns, bryophytes and algae. The diagram also includes the Holocene charcoal peak $(*)$, and the Pleistocene charcoal peak $(+)$.

\section{PALEOENVIRONMENTAL CONSIDERATIONS}

The absence of organic matter and clay in the medium sand facies of the FA I (2.30-1.19 m depth), older than 38,900 yrs BP, suggest the dominance of currents from the high-energy stream that carried out fine particles. In addition, the occurrence of the highest coarse sand proportion along the succession evidences that water bodies were not formed in this area.

The dominant herbal palynomorphs (Poaceae, Asteraceae and Apiaceae) from the shallow stream deposits at the base of the FA II (depth of 117 [m-fS/om] facies) with poor organic matter content, indicate an hipoautochtonous to parautochtonous origin linked to local and regional predominantly treeless vegetation (Jacobson \& Bradshaw, 1981; Prentice, 1985; Sugita, 1993, 1994). Pteridophytes were also rare, and podocarpacean pollen grains, as trace elements, were probably allochthonous and attributed to long-distance transport, given that during the Late Pleistocene, podocarp pollen grains appear periodically at multiple low-elevation sites (Behling et al., 1999; Haberle \& Maslin, 1999; Ledru et al., 2001; Niemann \& Behling, 2008) and as a rare occurrence in lowlands (Behling, 1995).

The dominance of anatomically poorly preserved small to medium size charcoal at the base of the FA II depth of $117 \mathrm{~m}$ ([m-fS/om] facies) with surface mineralization indicates that the charcoal is mainly allochthonous, i.e. remobilized from other depositional sites probably from shallow interconnected water bodies and transported into the depositional site, or 
alternatively from older geological units and re-deposited in Quaternary. The total homogenization of the cell wall in all fragments indicated the charcoal precede from high intensity fires.

The unusual preservation (which is different from the typical permineralization process as described by Dietrich et al., 2013) is the result of post-burial mineral infilling of charcoal and has been documented in Lower Permian (Uhl et al., 2004), Upper Triassic (Uhl \& Montenari, 2011; Cardoso et al., 2018), Jurassic, Pliocene (Scott \& Collinson, 2003), and Holocene (De Lafontaine et al., 2011) charcoal. Nevertheless, the rapid and intense percentage reduction of mineralized charcoal (to $5 \%$ of the association) at the depth of $107 \mathrm{~m}$ is an indicator that allochthonous or re-deposited charcoal were a relatively minor component and were no longer transported to the sedimentary environment.

The scarce but well preserved autochthonous aquatic elements represented by Botryococcus mats and Spirogyra spores from the depths of $117 \mathrm{~m}$ ([m-fS/om] facies) and $67 \mathrm{~cm}$ ([zy-f-mS/omc] facies) testify for the installation of a freshwater basin (Torgan et al., 2001; Medeanic, 2006; Ivanov et al., 2012). The pteridophyte increase (14.7\%) during the deposition in a shallow pond (depth of 67 $\mathrm{cm}$ ), in relation to their concentration in the basal facies [m-fS/om] at depth of $117 \mathrm{~cm}(2.7 \%)$, points to some increased wet environmental conditions on the margins of the pond, given that in extant floras Blechnum is an indicator of moist to wet environments from sea level to montane zones (Halverson et al., 1986; Klinka et al., 1989). The ecological preference of Blechnum for humid areas of open environments is ratified by the almost inexpressive presence of trees and shrubs in the pollen assemblages (Figure 4). The slight increase of spores of the autochthonous aquatic Spirogyra in the depth of $67 \mathrm{~cm}$ could testify for some wetter condition, given that this genus generally thrive in more nutrient rich environments.

The FA I and the basal facies of FA II [m-fS/mo] are correlated with warmer and wetter paleoclimatic conditions of the Dansgaard-Oeschger 8 (D-O 8), approximately 38 cal yrs $\mathrm{BP}$, enclosed in the interstadial Marine Isotopic Stage 3 (MIS 3), invigorating from 57 to 29 cal yrs BP (Rabassa \& Ponce, 2016). The deposition of coarser facies without clays, as result of streams located in the plain that follow basal sand ridge slope, is in accordance with warmer and wetter conditions of D-O 8 interval (Rabassa \& Ponce, 2016).

Along the FA II, the presence of burned fragments with distinct cell wall preservation (totally homogenized or partially homogenized walls) that indicate distinct fires intensity and the high proportions of small, similar sized particles are typical of background charcoal deposition (Higuera et al., 2010; Oris et al., 2014) (Figure 2 right). Such charred material might be included into the water body from potential different regional fire events that occurred away from the place of final deposition and transported selectively via hydraulic flow and also by winds.

The increase concentration of almost small, similar size charcoal fragments reaching the climax in the depth of $67 \mathrm{~cm}$ ([zy-f-mS/omc] facies) (Figures 2, 3C and D) testify for the increased occurrence of regional fire and selective charcoal transport of long-distance and deposition by water, during short wetter periods, and also by winds during drier periods. Such kind of peak is distinct from the typical charcoal peaks characterized by macroscopic charcoal assemblages with large diameters which are a good indicator of short dispersal distances and could be used to detect true local fire events (Oris et al., 2014).

This fire peak identified in the depth of $67 \mathrm{~cm}$ is older than 21,545 cal yrs BP, corresponding to the Last Glacial Maximum (Llanquihue Glaciation, Rabassa \& Clapperton, 1990; Lowell et al., 1995) when dry environmental conditions prevailed in the tropical-temperate belt of Southern Hemisphere (Peltier, 2004). The [zy-f-mS/omc] facies is correlated with drier and fully glacial climate of the of the Heinrich $2(\mathrm{H} 2)$, approximately $22 \mathrm{cal}$ yrs BP, pertained to the stadial Marine Isotopic Stage 2 (MIS 2), invigorating from 29 to $11,7 \mathrm{cal} \mathrm{yrs}$ BP (Rabassa \& Ponce, 2016).

Cross-correlation between the smooth charcoal peak and the palynological assemblages from the depth of $67 \mathrm{~cm}$ ([zy-f-mS/omc] facies) in pond depositional environment (Figure 4) indicates that regional fires were likely facilitated by the dominance of Poaceae in arid and xeric environments during dry climate intervals (Bremer \& Anderberg, 1994; Mondin, 2004), which can lead to the accumulation of large amounts of highly inflammable biomass (Pillar \& Quadros, 1997). Fuels in these environments desiccated quickly and were frequently dry enough to support fires even in nondrought years (Iglesias et al., 2015).

Evidence of regional fires documented by the presence of small background charcoal deposition persist during the youngest stage (FA III, correlated to the Lagoon-Barrier System III according Villwock et al., 1986 and Dillenburg et al., 2009), which record a change from a shallow and intermittent pond [zy-f-mS/om]. This interval possibly marks the transition from the Last Glacial Maximum stage to the Holocene, when the climate became wetter and warmer, to a peat-forming, organic matter-rich environment (Peat facies, $5,640-5,635 \mathrm{cal}$ yrs BP). This environmental change in the early Holocene seems to have been influenced by the rising sea-level (see Dillenburg et al., 2009).

The dominance of herb pollen grains (Poaceae) associated with significant pteridophyte spores (Blechnum) in the Peat 1 (35\% of organic matter content) and Peat 2 facies ( $65 \%$ of organic matter content) implies that these plants were common in the mainly treeless peat generating community and also in the environments surrounding the peat swamp. Studies performed by Bush (2002) in modern samples from Panama, Costa Rica and Ecuador, and those by Radaeski et al. (2016) and Radaeski \& Bauermann (2018) in southernmost Brazil, concluded that the representation of Poaceae pollen in the neotropics is influenced by many factors, and that high Poaceae abundance does not always indicate aridity. In addition, the importance of Blechnum spores along the peatland environment testify for its moist to wet environments in "water-receiving" sites (Halverson et al., 1986; Klinka et al., 1989). The poor representation of shrub and/or arboreal plants corroborates the 


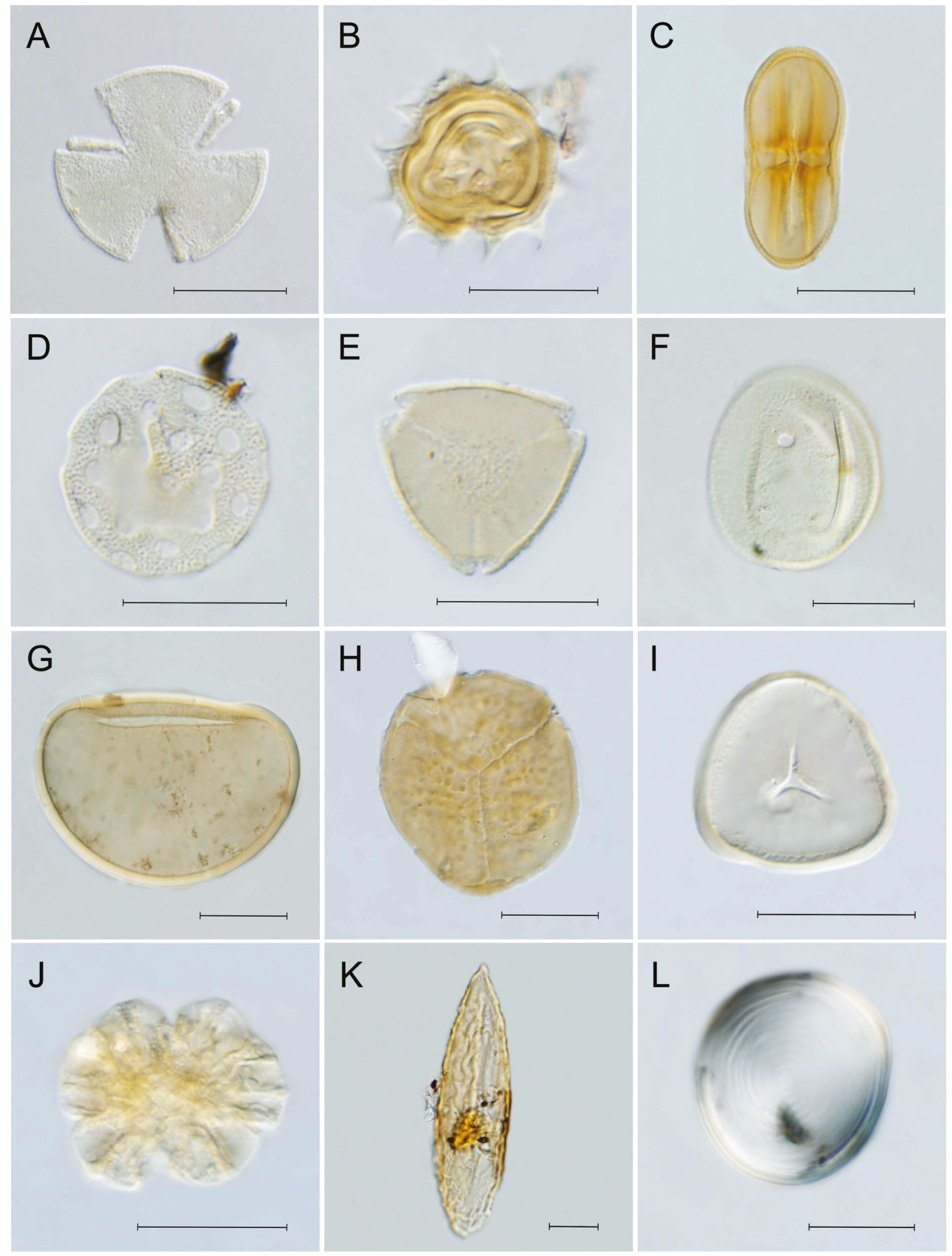

Figure 5. Photomicrographs of palynomorphs retrieved from the Águas Claras core. A, Alchornea Sw.; B, Asteraceae subf. Asteroideae; C, Apiaceae; D, Amaranthus/Chenopodiaceae; E, Myrtaceae; F, Poaceae; G, Blechnum L.; H, Phaeoceros Prosk.; I, Sphagnum L.; J, Botryococcus Kütz.; K, Spirogyra Link.; L, Pseudoschizaea rubina Rossignol ex Christopher. Scale bars $=20 \mu \mathrm{m}$. 
evidence of a predominantly treeless environment during the entire peat deposition interval (Figure 4).

The very low occurrence $(0.2 \%)$ of pollen grains of Podocarpaceae in the Holocene peat environment is attributed to allochthonous contribution and long-distance transport to the site of deposition. Ledru et al. (2007) combined pollen records with molecular analysis of living material to infer relationships among populations of Brazilian endemic species of Podocapaceae in different regions and concluded that the extant Podocarpus lambertii, a species associated with Araucaria forest, is related to the recent population expansion in the last 3,000 years in southern Brazil.

The occurrence of Pseudoschizaea, as an autochthonous aquatic element although scarce, just after the transition from shallow and intermittent pond [zy-f-mS/om] to a peat-forming environment (Peat 1 facies and Peat 2 facies), indicate the occurrence of seasonal dry-wet environmental changes in relatively warm climates where moisture is available (Scott, 1992). In addition, the expressive presence of Sphagnum spores in the peat generation interval, which is an ecologically prominent wetland plant with xerophytic adaptations, besides succession-directing acidification capabilities (Joly, 2002; Baptista et al., 2012) gives information about the peatland dynamics.

The increasing humidity in the peatland, inferred by different palynological indicators associated to the high enrichment in organic matter content $(65 \%)$ at the beginning of the deposition of the Peat 2 facies (depth of $18 \mathrm{~cm}$ ), is coincident with the Holocene maximum sea level in southernmost Brazil, dated as 5,600 cal yrs BP (Dillenburg et al., 2009).

A charcoal peak considered as an indicator of fires in the environments surrounding the peatland, as they likely were transported for short distances, comprising large size, well-preserved and non-abraded fragments, was recorded at a depth of $17 \mathrm{~cm}$ in the Peat 2 facies $(1,590-1,515$ cal yrs BP). The expressive size (up to $34 \mathrm{~mm}$ ) and the absence of abrasion of macro-charcoals recovered from the charcoal peak suggest that the fire events occurred very near from the place of final deposition (Scott, 2010) and hipoautochtonous sourced charcoals were transported inside the depositional environment via hydraulic flow and not by wind (Collinson $e t$ al., 2007) over a short distance into the mire. The absence of continuous bands of charred fragments, typical of smoldering ground burning of peat-forming material, withdraw an autochthonous source for the studied charcoals (Davies et al., 2013; Cohen et al., 1987). In modern peatland environments, under dry climatic conditions, especially during seasons of severe drought or during longer periods of reduced water tables, fire events are frequent even in wet biomes (Cypert, 1961; Staub \& Cohen, 1979; Ellery et al., 1989) (Figure 3).

The palynological spectrum of the vegetation at the charcoal peak at 1,590-1,515 cal yrs BP (Meghalayan Stage, according to Walker et al., 2018) indicate sharp changes in the palynomorph assemblages correlated with the fire occurrence at the area of peat deposition (Figure 6). The smaller concentration of pteridophytes, mainly represented by spores of Blechnum (18.4\%), compared to the $40.3 \%$ recorded in the underlying peat level (depth of $18 \mathrm{~cm}$ ), associated with the reduction of Sphagnum spores (from 20\% to $11.4 \%$ ), indicate decrease of humidity and drier conditions in the peatland area and its surroundings. This was presumably an important factor for the occurrence of fire, along with the presence of highly flammable biomass. After the fire event, wet environmental conditions persisted in the topmost Peat 2 facies at the depth of $14 \mathrm{~cm}$ (younger than 1,500 yrs BP).

Decreasing concentrations and sizes of fragments from the charcoal peak up to the top of the peat deposition (Figures 2 and 6) may indicate parautochthonous sources related to regional fire events, relatively far from the studied region. The soil level (11 to $0 \mathrm{~cm}$ deep), characterized by the dominance of arboreal forms of foreign species such as Pinus and Eucalyptus (Barth et al., 1976; Barboza et al., 2003), is related to human disturbance and not discussed in the present study.

\section{ORIGIN OF THE HOLOCENE FIRE EVENT}

According to biomass burning reconstructions included in the Global Charcoal Database, the Holocene fire event under study could be linked to increasing trends in biomass burning that peaked at approximately 1,500 yrs BP (Marlon et al., 2016). This event agrees with the reconstruction of regional and global temperatures for the past 11,300 years from Marcott et al. (2013), which indicates a warm interval

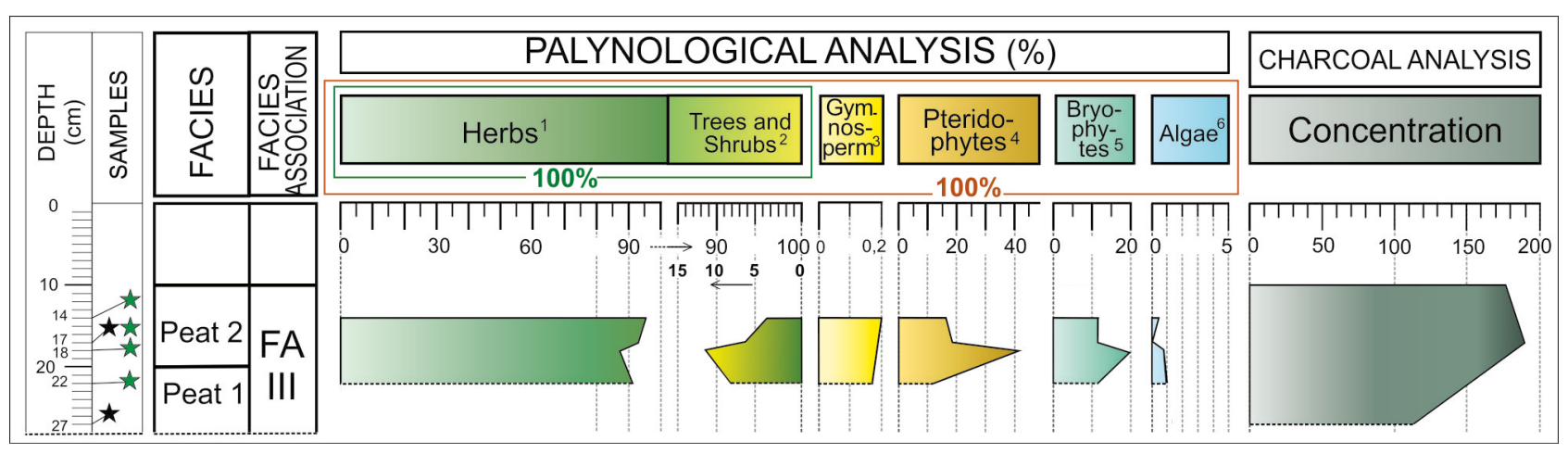

Figure 6. Integration of palynological and charcoal results for the Peat 1 facies from the Águas Claras core; percentage calculation: $1+2=100 \% ; 1+2+3+4+5+6$ $=100 \%$; black stars: charcoal; green stars: palynology. 
( $\sim 1,500$ to 1,000 yrs BP) transitioning to a cold interval from $\sim 500$ to 100 yrs BP.

Cross-correlation between the charcoal peak (a fire signal) and palynological assemblages of the Peat 2 facies shows that, at the interval of the charcoal peak, the palynological data show a sharp decrease in pteridophytes (mainly Blechnum) and bryophytes (mainly Sphagnum) in the peatland, as well as decrease in trees and shrubs in the land scape. This suggests a relationship between the change in plant group concentrations in wet environments and vegetational fire events, which occurred under exceptional very dry climatic conditions.

The fire event could be correlated with warm climate intervals included in global and regional temperatures reconstructed for the Holocene (Marcott et al., 2013) or alternatively with variations arising from atmosphere/ocean interactions agreeing to La Niña episode of ENSO amplitude around 1,500 yrs BP. However, the absence of studies with emphasis on ENSO intervals in southernmost South American Holocene prevents such inference. After the fire event (indicated by the charcoal peak at a depth of $17 \mathrm{~cm}$ ), wet environmental conditions returned to Águas Claras peatland.

An attempt to link the peak of fire with anthropogenic fire regime, i.e. human-induced ignition, considered the chronological range of pre-colonial occupation in Brazil's coastal regions. Copé (2012) identifies the presence of fisher-hunter-gatherers at 4,000 yrs BP, who lived by hunting, fishing, and gathering mollusks, at the Banhado Chico Lomã, near the region of the present study. Cultural characteristics of fisher-hunter-gatherer human groups that inhabited the coastal region of southern Brazil during the Late Holocene are not related to the occurrence of large fires since the food habit was derived from small-animal hunting, fishing, and plant collection (Rosa, 2010; Rosa \& Jacobus, 2010). This group did not use the fire targeting deforestation to prepare the ground for agriculture, which is an activity developed later with the European colonization (Copé, 2012). Besides, Scheel-Ybert et al. (2010) analyzed archaeological coals from the Late Holocene on the southern Brazilian coast, which indicated that fire was ignited from the dead-fallen wood, mainly for domestic use.

Bueno et al. (2013) hypothesized the riverine colonization model in the geographical context of central and northeastern Brazil between 13,000 and 8,000 yrs BP. Evidence of at least four occupation events was found in the northeast of Rio Grande do Sul State, called Sangão $\left(8,790 \pm 40{ }^{14} \mathrm{C}\right.$ BP $)$, Adelar Pilger $\left(8,430 \pm 50{ }^{14} \mathrm{C} \mathrm{BP}\right.$ and $\left.8090 \pm 35{ }^{14} \mathrm{C} \mathrm{BP}\right)$ and Garivaldino (averaged date of $8101 \pm 118{ }^{14} \mathrm{C} \mathrm{BP}$ ). These events, mostly during the Holocene, suggest that the human settlement was associated with the expansion of the Atlantic Forest biome, formerly restricted to mountain slopes and river valleys. At the coast, the spread of Atlantic Forest only occurred after the last maximum sea level event, at around 5,000 yrs BP.

The chronological control established from samples of charcoal from the archaeological site RS-S-327: Sangão $(8,800 \pm 40$ to $3,730 \pm 60 \mathrm{yrs} \mathrm{BP})$, which is near the area under study (some $44.6 \mathrm{~km}$ to the west), suggests that each bonfire represented a family group that inhabited the area. The immediate disposal pattern is associated with the domestic bonfire characteristic of sites of brief occupation (Dias, 2003). In addition to the published data dealing with a chronological range of pre-colonial occupation, the absence of evidence of human exploitation in the southernmost Brazilian coastal plain in this time interval $(1,590-1,515$ cal yrs BP) cannot confirm a relationship between human activities and extended fire. As discussed before, the palynological control (Figures 4 and 6) is an indicator that the charcoal peak, sourced by natural fire, was linked to a period of severe climatic drought.

\section{CONCLUSIONS}

The integration of charcoal, palynology, and faciological analyses provided the following conclusions:

- Fires occurred from the Late Pleistocene to the Late Holocene in the coastal plain of southernmost Brazil, as indicated by the presence of sedimentary charcoal in distinct shallow pond and peatland environments.

- The dominance of grassland vegetation (mainly Poaceae) in the Late Pleistocene scenario persisted into the Holocene during the development of a peatland.

- The charcoal peak identified in the sedimentary facies attributed to a shallow pond environment (older than 21,545 cal yrs BP), characterized by higher proportions of small, similar sized fragments in charcoal assemblages, points to the occurrence of regional fires in Late Pleistocene coastal plain of southernmost Brazil .

- A Meghalayan local fire event identified at the topmost level of the peat forming environment $(1,590-1,515 \mathrm{cal}$ yrs BP) was indicated by a sharp charcoal peak composed of high concentration of charcoal with large diameters.

- Fire evidence in the Holocene peatland environment was correlated with a change of the relative palynological abundance in the peat depositional site, indicated by a sharp decline of the pteridophyte (mainly Blechnum) and bryophyte spores (mainly Sphagnum), and provided evidence of anomalous drier conditions in potentially ever-wet environment.

- The Holocene charcoal peak is considered a signal of local, natural fire. Fuel availability, climate, and grassland vegetation type were the dominant drivers of biomass burning under a dry climate interval around 1,500-1,600 yrs BP.

\section{ACKNOWLEDGMENTS}

We thank Centro Polar e Climático, Departamento de Paleontologia e Estratigrafia, the Centro de Estudos de Geologia Costeira e Oceânica and the Instituto de Geociências of the Universidade Federal do Rio Grande do Sul (UFRGS) for field and laboratory assistance. Discussions with N.L.S. Gruber, S.R. Dillenburg and E.G. Barboza significantly improved the manuscript. Funding and scholarships were 
provided by the INCT-Criosfera (CNPq 465680/2014-3, 573720/2008-8 and FAPERGS 17/2551-0000518-0).

\section{REFERENCES}

Baptista, L.R.M.; Lorscheitter, M.L. \& Scherer, C. 2012. Floristic composition of a Subtropical bog, Eastern Plateau from southern Brazil. Check List, 8:224-236. doi:10.15560/8.2.224

Barboza, E.G.; Ayup-Zouain, R.N.; Tomazelli, L.J.; Rosa, M.L.C.C. \& Ferreira, H.P.L. 2005. Paleocanal pleistocênico na Barreira III entre o Chuí e o Balneário Hermenegildo-Rio Grande do Sul. In: CONGRESSO DA ASSOCIAÇÃO BRASILEIRA DE ESTUDOS DO QUATERNÁRIO, 10, 2005. Anais, Guarapari, ABEQUA.

Barboza, E.G.; Medeanic, S.; Guerra-Sommer, M. \& CazzuloKlepzig, M. 2003. Aplicação da palinologia como subsídio para o estudo estratigráfico da turfeira de Águas Claras, RS. In: CONGRESSO DA ASSOCIAÇÃO BRASILEIRA DE ESTUDOS DO QUATERNÁRIO, 9, 2003. Anais, Recife, ABEQUA.

Barth, O.M.; Barbosa, H.S. \& Macieira, E.G. 1976. Morfologia do pólen anemófilo e alegizante no Brazil: VI. Gramineae, Palmae, Typhaceae, Cyperaceae, Cupressaceae e Combretaceae. Memórias do Instituto Oswaldo Cruz, 74:347-359. doi:10.1590/ S0074-02761976000300013

Behling, H. 1995. Investigations into the Late Pleistocene and Holocene history of vegetation and climate in Santa Catarina (S Brazil). Vegetation History and Archaeobotany, 4:127-152. doi:10.1007/BF00203932

Behling, H.; Berrio, J.C. \& Hooghiemstra, H. 1999. Late Quaternary pollen records from the middle Caquetá river basin in central Colombian Amazon. Palaeogeography, Palaeoclimatology, Palaeoecology, 145:193-213. doi:10.1016/ S0031-0182(98)00105-9

Behling, H.; Pillar, V.D.; Orlóci, L. \& Bauermann, S.G. 2004. Late Quaternary Araucaria forest, grassland (Campos), fire and climate dynamics, studied by high-resolution pollen, charcoal and multivariate analysis of the Cambará do Sul core in southern Brazil. Palaeogeography, Palaeoclimatology, Palaeoecology, 203:277-297. doi:10.1016/S0031-0182(03)00687-4

Boldrini, I.L.; Ferreira, P.M.A.; Andrade, B.O.; Schneider, A.A.; Setúbal, R.B.; Trevisan, R. \& Freitas, E.M. 2010. Bioma Pampa: diversidade florística e fisionômica. Porto Alegre, Pallotti, $64 \mathrm{p}$.

Bowman, D.M.J.S et al. 2009. Fire in the Earth system. Science, 324:481-484. doi:10.1126/science. 1163886

Boyle, J.F.; Gaillard, M.J.; Kaplan, J.O. \& Dearing, J.A. 2011. Modelling prehistoric land use and carbon budgets: a critical review. The Holocene, 21:715-722. doi:10.1177/0959683610386984

Bremer, K. \& Anderberg, A.A. 1994. Asteraceae: cladistics and classification. Portland, Timber Press, $751 \mathrm{p}$.

Bueno, L.; Dias, A.S. \& Steele, J. 2013. The Late Pleistocene/Early Holocene archaeological record in Brazil: a geo-referenced database. Quaternary International, 301:74-93. doi:10.1016/j. quaint.2013.03.042

Bush, M.B. 2002. On the interpretation of fossil Poaceae pollen in the lowland humid neotropics. Palaeogeography, Palaeoclimatology, Palaeoecology, 177:5-17. doi:10.1016/ S0031-0182(01)00348-0

Cardoso, D.S.; Mizusaki, A.M.P.; Guerra-Sommer, M.; Menegat, R.; Barili, R.; Jasper, A. \& Uhl, D. 2018. Wildfires in the Triassic of Gondwana Paraná Basin. Journal of South American Earth Sciences, 82:193-206. doi:10.1016/j.jsames.2017.12.018
Clark, J.S. \& Royall, P.D. 1995. Particle-size evidence for source areas of charcoal accumulation in Late Holocene sediments of Eastern North American lakes. Quaternary Research, 43:80-89. doi:10.1006/qres.1995.1008.

Cohen, A.D.; Spackman, W. \& Raymond, R. 1987. Interpreting the characteristics of coal seams from chemical, physical and petrographic studies of peat deposits. In: A.C. Scott (ed.) Coal and coal-bearing strata: recent advances, London, Geological Society, p. 107-125. (Special Publication 32). doi:10.1144/GSL. SP.1987.032.01.08

Collinson, M.E.; Steart, D.C.; Scott, A.C.; Glasspool, I.J. \& Hooker, J.J. 2007. Episodic fire, run off and deposition at the PalaeoceneEocene boundary. Journal of the Geological Society, 164:87-97. doi:10.1144/0016-76492005-185

Copé, S.M. 2012. Diagnóstico arqueológico na LT 230KV-Se Viamão 3 - SE Restinga, Restinga, Porto Alegre 13, CEEE/ $R S$. Porto Alegre, Construtora PROCABLE Energia e Telecomunicações S/A \& Universidade Federal do Rio Grande do Sul. Relatório Técnico-Científico.

CPRM- Serviço Geológico do Brasil. 2006. Mapa Geológico do Estado do Rio Grande do Sul. Porto Alegre. Escala 1:750.000.

Cordeiro, R.C.; Turcq, B.; Suguio, K.; da Silva, A.O.; Sifeddine, A. \& Volkmer-Ribeiro, C. 2008. Holocene fires in East Amazonia (Carajás), new evidences, chronology and relation with paleoclimate. Global and Planetary Change, 61:49-62. doi:10.1016/j.gloplacha.2007.08.005

Cypert, E. 1961. The effects of fires in the Okefenokee Swamp in 1954 and 1955. American Midland Naturalist, 66:485-503. doi: $10.2307 / 2423049$

Daniau, A.L. et al. 2012. Predictability of biomass burning in response to climate changes. Global Biogeochemical Cycles, 26:1-12. doi:10.1029/2011GB004249

Davies, G.M.; Gray, A.; Rein, G. \& Legg, C.J. 2013. Peat consumption and carbon loss due to smoldering wildfire in a temperate peatland. Forest Ecology and Management, 308:169177. doi:10.1016/j.foreco.2013.07.051

De Lafontaine, G.; Couillard, P.L. \& Payette, S. 2011. Permineralization process promotes preservation of Holocene macrofossil charcoal in soils. Journal of Quaternary Science, 26:571-575. doi:10.1002/jqs. 1529

Dias, A.S. 2003. Sistemas de assentamento e estilo tecnológico: uma proposta interpretativa para a ocupação pré-colonial do Alto Vale do Rio dos Sinos, Rio Grande do Sul. Programa Interdepartamental de Pós-Graduação em Arqueologia, Universidade de São Paulo, Ph.D. thesis, 401 p.

Dietrich, D.; Lampke, T. \& Rößler, R. 2013. A microstructure study on silicified wood from the Permian petrified forest of Chemnitz. Paläontologische Zeitschrift, 87:397-407. doi:10.1007/s12542012-0162-0

Dillenburg, S.R.; Barboza, E.G.; Tomazelli, L.J.; Ayup-Zouain, R.N.; Hesp, P.A. \& Clerot, L.C. 2009. The Holocene Coastal Barriers of Rio Grande do Sul. In: S.R. Dillenburg \& P.A. Hesp (eds.) Geology and Geomorphology of Holocene Coastal Barriers of Brazil, Springer, p. 53-92. doi:10.1007/978-3-540-44771-9_3

Ellery, W.; Ellery, K.; McCarthy, T.S.; Cairncross, B. \& Oelofse, R. 1989. A peat fire in the Okavango Delta, Botswana, and its importance as an ecosystem process. African Journal of Ecology, 27:7-2. doi:10.1111/j.1365-2028.1989.tb00924.x

Faegri, K. \& Iversen, L. 1989. Textbook of pollen analysis. 4th ed. New York, John Wiley, 328 p.

Gavin, D.G.; Hu, F.S.; Lertzman, K. \& Corbett, P. 2006. Weak climatic control of stand-scale fire history during the Late 
Holocene. Ecology, 87:1722-1732. doi:10.1890/00129658(2006)87[1722:WCCOSF]2.0.CO;2

Green, D.G. 1981. Time Series and Postglacial Forest Ecology. Quaternary Research, 15:265-277. doi:10.1016/00335894(81)90030-2

Haberle, S.G. \& Maslin, M.A. 1999. Late Quaternary vegetation and climate change in the Amazon Basin based on a 50,000 year pollen record from the Amazon fan, ODP site 932. Quaternary Research, 51:27-38. doi:10.1006/qres.1998.2020

Halverson, N.M.; Rodahorst, A.; Topik, C.; Riley, J.; McClure, R.H. \& Lesher, R. 1986. Major indicator shrubs and herbs on national forests of western Oregon and southwestern Washington. Portland, Forest Service, Pacific Northwest Region, 196 p.

Hasenack, H.; Weber, E.; Boldrini, I.I. \& Trevisan, R. 2010. Mapa de sistemas ecológicos da ecorregião das Savanas Uruguaias em escala 1:500.000. Porto Alegre, UFRGS/Centro de Ecologia, 22 p.

Heyerdahl, E.K.; McKenzie, D.; Daniels, L.D.; Hessl, A.E.; Littell, J.S. \& Mantua, N.J. 2008. Climate drivers of regionally synchronous fires in the inland Northwest (1651-1900). International Journal of Wildland Fire, 17:40-49. doi:10.1071/ WF07024

Higuera, P.E.; Gavin, D.G.; Bartlein, P.J. \& Hallett, D.J. 2010. Peak detection in sediment-charcoal records: impacts of alternative data analysis methods on fire-history interpretations. International Journal of Wildland Fire, 19:996-1014. doi:10.1071/WF09134

Huber, U.M.; Markgraf, V. \& Schäbitz, F. 2004. Geographical and temporal trends in Late Quaternary fire histories of FuegoPatagonia, South America. Quaternary Science Reviews, 23:1079-1097. doi:10.1016/j.quascirev.2003.11.002

Iglesias, V.; Yospin, G.I. \& Whitlock, C. 2015. Reconstruction of fire regimes through integrated paleoecological proxy data and ecological modeling. Frontiers in Plant Science, 5:1-12. doi:10.3389/fpls.2014.00785

Ivanov, D.A.; Utescher, T.; Ashraf, A.R.; Mosbrugger, V.; Bozukov, V.; Djorgova, N. \& Slavomirova, E. 2012. Late Miocene palaeoclimate and ecosystem dynamics in Southwestern Bulgaria - a study based on pollen data from the Gotse-Delchev Basin. Turkish Journal of Earth Sciences, 21:187-211. doi:10.3906/ yer-1004-45

Jacobson, G.L. \& Bradshaw, R.H. 1981. The selection of sites for paleovegetational studies. Quaternary Research, 16:80-96. doi:10.1016/0033-5894(81)90129-0

Joly, A.B. 2002. Botânica: introdução à taxonomia vegetal. 13rd ed. São Paulo, Companhia Editora Nacional, 777 p.

Klinka, K.; Krajina, V.J.; Ceska, A. \& Scagel, A.M. 1989. Indicator plants of coastal British Columbia. Vancouver, UBC Press, $296 \mathrm{p}$.

Larsen, C.P.S. \& MacDonald, G.M. 1998. Fire and vegetation dynamics in a jack pine and black spruce forest reconstructed using fossil pollen and charcoal. Journal of Ecology, 86:815828. doi:10.1046/j.1365-2745.1998.8650815.x

Ledru, M.; Cordeiro, R.C.; Dominguez, J.M.L.; Martin, L.; Mourguiart, P.; Sifeddine, A. \& Turcq, B. 2001. Late-Glacial cooling in Amazonia inferred from pollen at Lagoa do Caçó, Northern Brazil. Quaternary Research, 55:47-56. doi:10.1006. qres.2000.2187

Ledru, M.P.; Salatino, M.L.F.; Ceccantini, G.; Salatino, A.; Pinheiro, F. \& Pintaud, J.C. 2007. Regional assessment of the impact of climatic change on the distribution of a tropical conifer in the lowlands of South America. Diversity and Distributions, 13:761-771. doi:10.1111/j.1472-4642.2007.00389.x

León, R.J.C. 1991. Río de la Plata grasslands. In: R.T. Coupland (ed.) Ecosystems of the World. Natural grasslands: introduction and western hemisphere, Elsevier, p. 369-376, 380-387.

Lowell, T.V.; Heusser, C.J.; Andersen, B.G.; Moreno, P.I.; Hauser, A.; Heusser, L.E.; Schlüchter, C.; Marchant, D.R. \& Denton, G.H. 1995. Interhemispheric correlation of Late Pleistocene glacial events. Science, 269:1541-1549. doi:10.1126/science.269.5230.1541

Marcott, S.A.; Shakun, J.D.; Clark, P.U. \& Mix, A.C. 2013. A reconstruction of regional and global temperature for the past 11,300 years. Science, 339:1198-1201. doi:10.1126/ science. 1228026

Markgraf, V.; Iglesias, V. \& Whitlock, C. 2013. Late and postglacial vegetation and fire history from Cordón Serrucho Norte, northern Patagonia. Palaeogeography, Palaeoclimatology, Palaeoecology, 371:109-118. doi:10.1016/j.palaeo.2012.12.023

Marlon, J.R.; Bartlein, P.J.; Daniau, A.L.; Harrison, S.P.; Maezumi, S.Y.; Power, M.J.; Tinner, W. \& Vanniére, B. 2013. Global biomass burning: a synthesis and review of Holocene paleofire records and their controls. Quaternary Science Reviews, 65:5-25. doi:10.1016/j.quascirev.2012.11.029

Marlon, J.R. et al. 2009. Wildfire responses to abrupt climate change in North America. Proceedings of the National Academy of Sciences of the United States of America, 106:2519-2524. doi:10.1073/pnas.0808212106

Marlon, J.R.; Kelly, R.; Daniau, A.L.; Vannière, B.; Power, M.J.; Bartlein, P.; Higuera, P.; Blarquez, O.; Brewer, S.; Brücher, T. et al. 2016. Reconstructions of biomass burning from sediment charcoal records to improve data-model comparisons. Biogeosciences, 13:3225-3244. doi:10.5194/bg-13-3225-2016

Masson-Delmotte, V. et al. 2013. Information from paleoclimate archives. In: T.F. Stocker, D. Qin, G.K. Plattner, M. Tignor, S.K. Allen, J. Doschung, A. Nauels, Y. Xia, V. Bex \& P.M. Midgley (eds.) Climate Change 2013: the physical science basis. Contribution of working group I to the Fifth Assessment Report of the Intergovernmental Panel on Climate Change, Cambridge University Press, p. 383-464. doi:10.1017/ CBO9781107415324.013.

Medeanic, S. 2006. The palynomorphs from surface sediments of intertidal marshes in the estuarine part of the Patos Lagoon. Iheringia, Série Botânica, 61:49-62.

Miall, A.D. 1992. Alluvial deposits. In: R.G. Walker \& N.P James (eds.) Facies Models. Response to Sea Level Change, Geological Association of Canada, p. 119-142.

Mondin, C.A. 2004. Two new species of Smallanthus (Asteraceae: Heliantheae) from Brazil. Compositae Newsletter, 41:1-8.

Mosimann, J.E. 1965. Statistical methods for the pollen analyst multinomial and negative multinomial techniques. In: B. Kummel \& D. Raup (eds.) Handbook of Paleontological Techniques, Freeman, p. 636-673.

Mourelle, D.; Macedo, R.B. \& Prieto, A.R. 2018. Análisis palinológico actual y del Cuaternario Tardío en la región de los Campos (Uruguay y sur de Brasil): estado de las investigaciones, dificultades y potencialidades. Publicación Electrónica de la Asociación Paleontológica Argentina, 18:156-170. doi:10.5710/ PEAPA.28.05.2018.258

Niemann, H. \& Behling, H. 2008. Late Quaternary vegetation, climate and fire dynamics inferred from the El Tiro record in the 
southeastern Ecuadorian Andes. Journal of Quaternary Science, 23:203-212. doi:10.1002/jqs. 1134

Oris, F.; Ali, A.A.; Asselin, H.; Paradis, L.; Bergeron, Y. \& Finsinger, W. 2014. Charcoal dispersion and deposition in boreal lakes from 3 years of monitoring: differences between local and regional fires. Geophysical Research Letters, 41:6743-6752. doi:10.1002/2014GL060984

Paduano, G.M.; Bush, M.B.; Baker, P.A.; Fritz, S.C. \& Seltzer, G.O. 2003. A vegetation and fire history of Lake Titicaca since the Last Glacial Maximum. Palaeogeography, Palaeoclimatology, Palaeoecology, 194:259-279. doi:10.1016/ S0031-0182(03)00281-5

Patterson, W.A. \& Backman, A.E. 1988. Fire and disease history of forests. In: B. Huntley \& T. Webb (eds) Vegetation history, Springer, p. 603-632. doi:10.1007/978-94-009-3081-0_16

Peltier, W.R. 2004. Global glacial isostasy and the surface of the ice-age Earth: the ICE-5G (VM2) model and GRACE. Annual Review of Earth and Planetary Sciences, 32:111-149. doi:10.1146/annurev.earth.32.082503.144359

Pillar V.D. \& Quadros F.L.F. 1997. Grassland-forest boundaries in southern Brazil. Coenoses, 12:119-26. doi:10.1007/978-30348-8722-9 17

Power, M.J. et al. 2008. Changes in fire regimes since the Last Glacial Maximum: an assessment based on a global synthesis and analysis of charcoal data. Climate dynamics, 30:887-907. doi: 10.1007/s00382-007-0334-x

Prentice, I.C. 1985. Pollen representation, source area, and basin size: toward a unified theory of pollen analysis. Quaternary Research, 23:76-86. doi:10.1016/0033-5894(85)90073-0

Rabassa, J. \& Clapperton, C.M. 1990. Quaternary glaciations of the southern Andes. Quaternary Science Reviews, 9:153-174. doi:10.1016/0277-3791(90)90016-4

Rabassa, J. \& Ponce, J.F. 2016. The Heinrich and DansgaardOeschger climatic events during Marine Isotopic Stage 3. In: M. Gasparini, J. Rabassa, C. Deschamps \& E.P. Tonni (eds.) Marine Isotope Stage 3 in Southern South America, 60 ka B.P.-30 ka B.P., Springer, p. 7-21. doi:10.1007/978-3-319-40000-6_2

Radaeski, J.N. \& Bauermann, S.G. 2018. Poaceae pollen grains from southern Brazilian grasslands: pollen grain size in species from dry and humid environments. Neotropical Biology and Conservation, 13:111-123. doi:10.4013/nbc.2018.132.03

Radaeski, J.N.; Bauermann, S.G. \& Pereira, A.B. 2016. Poaceae pollen from Southern Brazil: distinguishing grasslands (campos) from forests by analyzing a diverse range of Poaceae species. Frontiers in plant science, 7:1833. doi:10.3389/ fpls.2016.01833

Rhodes, T.E. \& Davis, R.B. 1995. Effects of Late Holocene forest disturbance and vegetation change on acidic mud pond, Maine, USA. Ecology, 76:734-746. doi:10.2307/1939340

Rosa, A. 2010. Análise zooarqueológica do sítio Garivaldino (RSTQ-58), município de Montenegro, RS. Pesquisas-Antropologia, 67:133-172.

Rosa, A. \& Jacobus, A. 2010. Registro de mamíferos em sítios arqueológicos do Rio Grande do Sul, Brasil. In: A.M. Ribeiro., S. Bauermann \& C. Scherer (eds.) Quaternário do Rio Grande do Sul, Sociedade Brasileira de Paleontologia, p. 233-242.

Scheel-Ybert, R.S.; Caromano, C.F.; Cascon, L.M.; Bianchini, G.F. \& Beauclair, M. 2010. Estudos de paleoetnobotânica, paleoambiente e paisagem na Amazônia Central e o exemplo do sudeste-sul do Brasil. In: E. Pereira \& V. Guapindaia (eds.) Arqueologia Amazônica, Museu Paraense Emílio Goeldi, p. 909-935.
Scott,A.C. 2000. The Pre-Quaternary history of fire. Palaeogeography, Palaeoclimatology, Palaeoecology, 164:281-329. doi:10.1016/ S0031-0182(00)00192-9

Scott, A.C. 2010. Charcoal recognition, taphonomy and uses in palaeoenvironmental analysis. Palaeogeography, Palaeoclimatology, Palaeoecology, 291:11-39. doi:10.1016/j. palaeo.2009.12.012

Scott, A.C. \& Collinson, M.E. 2003. Non-destructive multiple approaches to interpret the preservation of plant fossils: implications for calcium-rich permineralizations. Journal of the Geological Society, 160:857-862. doi:10.1144/0016764902-163

Scott, L. 1992. Environmental implications and origin of microscopic Pseudoschizaea Thiergart and Frantz ex R. Potonié emend. in sediments. Journal of Biogeography, 19:349-354. doi: $10.2307 / 2845562$

Staub, J.R. \& Cohen, A.D. 1979. The snuggedy swamp of South Carolina: a back-barrier estuarine coal-forming environment. Journal of Sedimentary Research, 49:133-143. doi:10.1306/212F76D5-2B24-11D7-8648000102C1865D

Stevaux, R. \& Dillenburg, S.R. 2011. Propriedades Sedimentológicas e Mineralógicas das Barreiras Costeiras do Rio Grande do Sul: uma análise preliminar. In: XIII CONGRESSO DA ASSOCIAÇÃO BRASILEIRA DE ESTUDOS DO QUATERNÁRIO, 2011. Anais do XIII Congresso da Associação Brasileira de Estudos do Quaternário: III Encontro do Quaternário Sul-Ameriano, 2011. Armação dos Búzios: ABEQUA, p. 213-217.

Sugita, S. 1993. A model of pollen source area for an entire lake surface. Quaternary Research, 39:239-244. doi:10.1006/ qres.1993.1027

Sugita, S. 1994. Pollen representation of vegetation in Quaternary sediments: theory and method in patchy vegetation. Journal of Ecology, 82:881-897. doi:10.2307/2261452

Tomazelli, L.J. \& Villwock, J.A. 1996. Quaternary geological evolution of Rio Grande do Sul coastal plain, southern Brazil. Anais Academia da Brasileira de Ciências, 68:373-382.

Torgan, L.C.; Barreda, K.D.A. \& Fortes, D.F. 2001. Catálogo das algas Chlorophyta de águas continentais e marinhas do estado do Rio Grande do Sul, Brasil. Iheringia, Série Botânica, 56:147-183.

Uhl, D.; Lausberg, S.; Noll, R. \& Stapf, K.R.G. 2004. Wildfires in the Late Palaeozoic of Central Europe-an overview of the Rotliegend (Upper Carboniferous-Lower Permian) of the Saar-Nahe Basin (SW-Germany). Palaeogeography, Palaeoclimatology, Palaeoecology, 207:23-35. doi:10.1016/j. palaeo.2004.01.019

Uhl, D. \& Montenari, M. 2011. Charcoal as evidence of palaeowildfires in the Late Triassic of SW Germany. Geological Journal, 46:34-41. doi:10.1002/gj.1229

Villwock, J.A. \& Tomazelli, L.J. 1995. Geologia costeira do Rio Grande do sul. Notas Técnicas, 8:1-45.

Villwock, J.A.; Tomazelli, L.J.; Loss, E.L.; Dehnhardt, E.A.; Horn, P.N.O.; Bachi, F.A. \& Dehnhardt, B.A. 1986. Geology of the Rio Grande do Sul Coastal Province. In: J. Rabassa (ed.) Quaternary of South America and Antarctic Peninsula, Balkema, 4:79-97.

Walker, M.; Head, M.J.; Berkelhammer, M.; Björck, S.; Cheng, H.; Cwynar, L.; Fisher, D.; Gkinis, V.; Long, A.; Lowe, J.; Newnham, R.; Rasmussen, S.O. \& Weiss, H. 2018. Formal ratification of the subdivision of the Holocene Series/Epoch (Quaternary System/Period): two new Global Boundary Stratotype Sections and Points (GSSPs) and three new 
stages/subseries. Episodes, 41:213-223. doi:10.18814/ epiiugs/2018/018016

Walker, R.G. 1992. Facies, facies models and modern stratigraphic concepts. In: R.G. Walker \& N.P. James (eds.) Facies models: response to sea level change, Geological Association of Canada, p. 1-14.

Walker, R.G. 2006. Introduction. In: H.W. Posamentier \& R.G. Walker (eds.) Facies Models Revisited, Special Publications SEPM 84, p.1-17.

Wetzel, R.G. 1975. Limnology. Philadelphia, W.B. Saunders Company, $743 \mathrm{p}$.

Whitlock, C. \& Bartlein, P.J. 2003. Holocene fire activity as a record of past environmental change. Developments in Quaternary Science, 1:479-490. doi:10.1016/S1571-0866(03)01022-4
Whitlock, C.; Moreno, P.I. \& Bartlein, P. 2007. Climatic controls of Holocene fire patterns in southern South America. Quaternary Research, 68:28-36. doi:10.1016/j.yqres.2007.01.012

Ybert, J.P.; Salgado-Labouriau, M.L.; Barth, O.M.; Lorscheitter, M.L.; Barros, M.A.; Chaves, S.A. M.; Luz, C.F.P.; Ribeiro, M.; Scheel, R. \& Vicentini, K.F. 1992. Sugestões para padronização da metodologia empregada em estudos palinológicos do Quaternário. Revista do Instituto Geológico, 13:47-49. doi:10.5935/0100-929X.19920009

Received in 25 March, 2020; accepted in 12 October, 2020. 